\title{
Maize: Key agricultural crop in food security and sovereignty in a future with water scarcity
}

\author{
Josana A. Langner ${ }^{1}$, Alencar J. Zanon ${ }^{2}$, Nereu A. Streck ${ }^{2}$, Lia R. S. Reiniger ${ }^{2}$, \\ Marielen P. Kaufmann ${ }^{3}$ \& Alexandre F. Alves ${ }^{1}$
}

${ }^{1}$ Universidade Federal de Santa Maria/Pós-Graduação em Engenharia Agrícola. Santa Maria, RS, Brasil. E-mail: langnerja@gmail.com (Corresponding author) -
ORCID: 0000-0002-6949-2686; alexandreferigolo@gmail.com - ORCID: 0000-0002-6610-3104
${ }^{2}$ Universidade Federal de Santa Maria/Departamento de Fitotecnia. Santa Maria, RS, Brasil. E-mail: alencarzanon@yahoo.com.br - ORCID: 0000-0002-7194-9833;
nstreck2@yahoo.com.br - ORCID: 0000-0002-2495-0823; liarsr@ufsm.br - ORCID: 0000-0002-3243-671X
${ }^{3}$ Universidade Federal do Rio Grande do Sul/Programa de Pós-Graduação em Desenvolvimento Rural. Porto Alegre, RS, Brasil. E-mail: marielenpk@hotmail.com
- ORCID: 0000-0003-1041-7531

\begin{abstract}
The objective in this review was to discuss the importance of maize currently and the crucial role it may play in the future for food production in scenarios of water shortage, as well as the importance of conserving its landrace cultivars, which have a considerable portion of the reserve of genetic variability. Maize plants, when exposed to water deficit, may develop physiological, morphological, biochemical and anatomical adaptation mechanisms. With the aid of genetic improvement, characteristics that impart tolerance are fixed in plants through conventional methods. In this context, 'Tuxpeño Sequia' cultivars were developed in Mexico, while in Africa, one of the most important strategies was the development of 'DT' (Drought-tolerant) cultivars. In the United States, one of the most important processes was the development of PionerAquamax ${ }^{\infty}$ hybrids, while in Brazil, it was the development of cultivars with the 'Maya Latente' gene. Through genetic transformation, the hybrid 'MON 87460' was developed. However, it should be mentioned that, for a cultivar to be well accepted by producers, besides having one or more adaptation characteristics, it must have a high grain yield. Biotechnological tools such as the use of molecular markers, genetic transformation, and modeling through bioinformatics, associated with conventional selection, will be fundamental to guarantee the advancement of water deficit tolerance in maize.
\end{abstract}

Key words: Zea mays L., foods, landrace cultivars, climate change

\section{Milho: Cultura agrícola chave na segurança e soberania alimentar num futuro com escassez de água}

RESUMO: O objetivo nesta revisão foi discutir a importância da cultura do milho na atualidade e o papel crucial que pode desempenhar no futuro para a produção de alimentos em cenários de deficiência hídrica, bem como a importância de conservar suas cultivares crioulas, que detêm uma parcela considerável dessa reserva de variabilidade genética. As plantas de milho, quando expostas à deficiência hídrica, podem desenvolver mecanismos fisiológicos, morfo-anatômicos, bioquímicos e moleculares de adaptação. Com o auxílio do melhoramento genético são fixadas nas plantas as características adaptativas que conferem tolerância via métodos convencionais, com a seleção e incorporação da característica, ou pelo emprego de transformação genética. Nesse sentido, foram desenvolvidas, por meio do melhoramento convencional, a cultivar Tuxpeño Sequia, no México, enquanto na África, uma das estratégias mais importantes foi o desenvolvimento das cultivares DT (Drought-tolerant). Já nos Estados Unidos, um dos processos mais importantes foi o desenvolvimento dos híbridos PionerAquamax ${ }^{\circledast}$ ao passo que, no Brasil, foi o desenvolvimento das cultivares possuidoras do caráter latente na cultivar Maya Latente. Por meio da transformação genética foi desenvolvido o híbrido 'MON 87460'. Entretanto, deve ser mencionado que, para uma cultivar ser bem aceita pelos produtores, além de possuir uma ou mais características de adaptação, precisa ter alta produção de grãos. Ferramentas biotecnologicas como uso de marcadores moleculares, transformação genética, e modelagem através da bioinformática, associadas à seleção convencional, serão fundamentais para garantir o avanço na tolerância à deficiência hídrica em milho.

Palavras-chave: Zea mays L., alimentos, cultivares crioulas, mudança climática 


\section{INTRODUCTION}

In scenarios with increased frequency of extreme events, such as water deficit, according to forecasts of the Intergovernmental Panel on Climate Change (IPCC, 2014), the maize crop and its landrace cultivars are fundamental to ensure food security and sovereignty. Water deficit is the most severe cause of reduction in the global agricultural production, and climate change tends to aggravate this scenario (Ribaut et al., 2009). Additionally, there is the challenge of increasing food supply in the stress scenarios by about $60 \%$, coupled to the increase in the world population, which will exceed 9 billion people by 2050 (Grassini et al., 2015).

To ensure maize production in water stress scenarios, there are many strategies, which include especially the development of cultivars that are tolerant to water deficit by means of genetic improvement. Such tolerance can be obtained by means of hybridization, with genetic materials with broad genetic variability and which can manifest mechanisms of adaptation (Taiz \& Zieger, 2013). In this context, landrace cultivars are preferred because they have a great reserve of genetic variability, of genes that guarantee better adaptation to stresses (Machado et al., 2011). In addition to the conventional methodology, it is also possible to use genetic transformation, with the obtaining of transgenic cultivars, such as the hybrid 'MON 87460', which is a transgenic maize cultivar with drought tolerance that has the Droughtgard ${ }^{\oplus}$ trait (Chang et al., 2014).

To ensure the production of maize destined to feeding a growing population and in scenarios of increased lack of water, it is necessary to broaden the research on genetic improvement, in order to contemplate the tolerance to this stress. The present review aimed to discuss the importance of the maize crop nowadays and the crucial role it can play in the future for food production in water deficit scenarios, as well as the importance of conserving its landrace cultivars as sources of genetic variability useful for genetic improvement.

\section{History of Maize Crop}

The currently cultivated maize (Zea mays ssp. Mays) originates from the human interaction, from wild ancestors, the teosinte, of the parviglumis and Mexican subspecies (Zea mays ssp. parviglumis), performed about 9000 years ago by the peoples of Central America, particularly of Mexico (Prasanna, 2012). The probable place of domestication is the CentralSouth region of Mexico, at average altitudes of approximately $1500 \mathrm{~m}$ above sea level. Currently, the cultivation is carried out all over the world, at several latitudes (ranging from $58^{\circ}$ $\mathrm{N}$ to $40^{\circ} \mathrm{S}$ ) and altitudes (from $3500 \mathrm{~m}$ to sea level), which demonstrates its wide adaptability (Fancelli \& Dourado Neto, 2000).

Maize was the food base which allowed the development of several important civilizations over the centuries, such as the Incas, in Peru and in a wide region located in the Andes, the Aztecs, in Mexico, and the Maya, in Central America and Southern Mexico. The navigators were the ones who took maize seeds to Europe, Asia and Africa, and today, in the African continent, this cereal is the most cultivated crop and with the highest total grain yield (Prasanna, 2012; FAOSTAT, 2018). In South America, it is estimated that maize cultivation began over 4000 years ago by indigenous people, who planted different cultivars according to the purpose of use (Perry et al., 2006).

In Brazil, maize was already cultivated by the indigenous people as well, both for food and for other purposes, before the Portuguese navigators arrived in the country (Krug, 1966). After the arrival of the colonizers, maize consumption increased due to the population growth and the diversity of uses, not only for human food, but also for the feeding of domestic animals, making maize one of the most important sources of income in family farms. The species became a constituent part of the food culture of the Brazilian population from North to South of the country, because it is present in a variety of foods, such as pamonha, porridge, cuscuz, among other derivatives produced from maize flour.

\section{ECONOMIC AND SOCIAL IMPORTANCE OF MAIZE}

Maize is cultivated in almost all countries, occupying an area of approximately 160 million hectares (Silva et al., 2017). In nutritional terms, maize has a carbohydrate-rich composition, mainly in the form of starch, and also has proteins, lipids, vitamins and minerals (Oliveira et al., 2014). One important feature is that grains can be directly consumed, without the need for processing to remove the hull as it is done with other cereals, such as rice and wheat. In sub-Saharan Africa, maize is the most important agricultural species, both for being the most cultivated and produced in quantitative terms and for being the one which supplies 40 to $50 \%$ of the calories and proteins consumed in Malawi, Zimbabwe and Zambia (Prasanna, 2012; Cairns et al., 2013). In Zambia, maize is the most important cereal, and about $90 \%$ of the maize produced is used for human consumption (Edmeades et al., 1996).

In the production systems of commercial plantations, there is a greater economic investment, aiming at obtaining higher yields with higher level of management, through the chemical control of insects and diseases, greater application of fertilizers, use of irrigation and seeds of hybrid cultivars (Argenta et al., 2003). Hybrids are developed by following methodologies with scientific nature and show characteristics such as high production, response to fertilizers, short stature and synchronicity in the development (Machado et al., 2008). The crossing of previously selected endogamous strains leads to a $F_{1}$ generation with high phenological, morphological and genetic uniformity, and demanding with respect to environment to express all its production potential (Argenta et al., 2003). On the other hand, if the farmer uses grains produced from $\mathrm{F}_{1}$, the generation $\mathrm{F}_{2}$, as seeds in the next season, will undergo a reduction in production, and the plants will be greatly uneven. The need to purchase new seeds at each season raises the costs of production, since the seeds of $\mathrm{F}_{1}$ hybrid are commercialized with very high values, and it also makes the farmer dependent on the seed-producing companies.

Alternatively, it is also possible to use seeds of the intervarietal hybrids of maize (hybrids of $\mathrm{F}_{2}$ maize populations), and open pollinated varieties (or cultivars) (OPV), which are 
obtained by free pollination between maize plants. Therefore, they are highly heterozygous and heterogeneous, with the characteristic of having greater production stability and genetic variability (Fritsche-Neto \& Môro, 2015). They are a great alternative to reduce costs in farms or in areas around the world with low technological level, as in family farms in RS and northeast of Brazil or African continent. OPV can be developed either in formal improvement programs or by farmers themselves in their rural properties. The OPV maintain or even increase yield in the $\mathrm{F}_{2}$ and advanced generations, which allows farmers, besides cultivating, to produce their own seed.

The seeds of cultivars that are produced and preserved by the farmer themselves receive several denominations, such as landrace seed, natural seed, domestic seed, traditional variety, among other nomenclatures (Meirelles \& Rupp, 2006). These cultivars are part of the group of local, traditional or landrace cultivars. Local cultivars are those cultivated by farmers continuously for five or more cycles of selection and cultivation. Traditional cultivars are those managed by at least three family generations, in the same ecosystem, when historical values are incorporated, and it becomes part of the local traditions (Machado et al., 2008). Landrace cultivars are denominated in latin countries as the local or traditional, and this denomination is used in the present review.

Landrace cultivars also have the characteristic of being cultivated by families for different purposes, such as the important role in the promotion of organic production systems, because the increase of diversity favors the stability of the systems, favoring the empowerment of traditional communities and family farmers (Boef et al., 2013). Some of them are specific for flour production, while others are used for the consumption of green maize, for the use of straw in craftwork and also to feed animals. In addition, landrace cultivars have greater genetic variability, being an important source of genes of resistance to biotic stress and tolerance to abiotic stresses, such as those expected to occur due to climatic changes (Sandri \& Tofanelli, 2008; IPCC, 2014).

When seeds of landrace cultivars are lost or disappear, there is also a loss of biodiversity, culture and historical traditions of families and communities (Bianchetto et al., 2017). From the emergence of maize hybrids, numerous cultivars adapted to specific regions have been replaced by a limited number of hybrid cultivars, which were created from a large genetic basis (Clerc et al., 2005). However, the main hybrids cultivated today in the world are developed with a low number of strains, with almost limited genetic diversity, compared to that stored in the seed banks.

One of the strategies used to minimize the loss of biodiversity is conservation, which can be done ex-situ, in-situ or in a combined manner. Ex-situ conservation is performed outside the natural habitat, when the seeds are stored in seed or germplasm banks. In Mexico, seeds are stored in the International Maize and Wheat Improvement Center (CIMMYT), more than 27000 samples of maize seeds, representing about $90 \%$ of the maize diversity in the Americas (Ortiz et al., 2008). In Brazil, 3,816 representative samples of maize germplasm are stored in the Active Bank of
Maize Germplasm (BAG), located at Embrapa Milho e Sorgo (Andrade et al., 2002).

By contrast, in-situ conservation is the one carried out in the original environment in which the species was domesticated or in the place where it developed characteristics that make it different. This strategy can be performed on the farm, when it is done in the family property. In this form of conservation, the cultivars continue to evolve, through processes to which they are continually subjected, resisting environmental and economic changes.

Kaufmann and collaborators pointed out the importance of integrated conservation of landrace agrobiodiversity, especially for maize (Kaufmann et al., 2018). This modality is characterized by the alliance between ex-situ conservation, which allows the characterization and storage of the cultivars, and in-situ conservation (on farm), carried out mainly by indigenous and traditional peoples, allowing these populations which manage the cultivars to maintain their process of adaptation to the environments, and according to the interests of the communities, ensuring their food security. This type of conservation strategy is also interesting to guarantee the expression of the genetic diversity of maize cultivars, which favors the emergence of genes of tolerance to adverse factors of the climate.

\section{Water Stress in Maize}

Due to the characteristic of high sensitivity to water deficit in a relatively short period of the cycle (flowering-grain filling), maize production has a close relation with water availability (Berlato et al., 2005). For maize, the highest water requirements are concentrated in the vegetative, pre-flowering and flowering, and grain filling stages (Bergamaschi \& Matzenauer, 2014). The period encompassing the pre-flowering and flowering is the phase of highest sensitivity, which can compromise the entire production (Fancelli \& Dourado Neto, 2000). Higher sensitivity in the reproductive period occurs because of the physiological processes related to zygote formation and the beginning of the grain filling, in addition to the high transpiration caused by the maximum leaf area reached at this stage of development (Bergamaschi \& Matzenauer, 2014). Water stress in maize plants causes delay in the emergence of stigmata, resulting in an increase in the interval between male and female flowering, and also in high percentage of aborted zygotes after fertilization (Bernini et al., 2016). The most prominent responses of plants to water deficit are the reduction in leaf area production, stomatal closure, senescence acceleration and leaf abscission.

In the case of Brazil, specifically in tropical and subtropical regions, there is seasonality of rainfall, where periods with excess and others with deficit of water often prevail, which result in fluctuations in grain production. In RS, Brazil, the dry spells and droughts occur due to the influence of the phenomenon El Niño South Oscillation (ENSO). ENSO is characterized by the abnormal heating or cooling of the waters of the Equatorial Pacific Ocean. The occurrence of cooling characterizes the action of La Niña, which results in reduction of rainfall, mainly in the spring and early summer, causing water deficit for summer crops (Berlato et al., 2005). 
Analyzing the historical series from 1919 to 2003, Berlato et al. (2005) demonstrated that, for the years of El Niño in southern Brazil and in other countries such as Argentina, the maize sown during the recommended period had higher frequency of high production, while for La Niña there was higher frequency of low production. Yield losses around 3.4 million tons (IBGE, 2010) were recorded in the RS, Brazil, in the 2004/2005 season, year of El Niño with a different configuration, called El Niño Modoki, with characteristics of reduction of rainfall in the summer months (Tedeschi et al., 2013). In the 2011/2012 season, the losses were equal to $46.7 \%$, which corresponded to 3 million tons of grain (EMATER, 2012).

\section{Mechanisms Developed by Plants to Tolerate Water Stress}

When under water stress, plants can respond by developing mechanisms of morpho-anatomical, biochemical, physiological and molecular adaptation (Taiz \& Zieger, 2013). Physiological alterations correspond to changes which occur at the cellular level, such as leaf water potential, stomatal conductance and chlorophyll content; morpho-anatomical alterations correspond to the increase in the interval, in days, between female and male flowering, accelerated senescence of culms and leaves, reduction in plant height, prolificacy, number of branches of the tassel and total dry matter (Bernini et al., 2016). The physiological alterations which guarantee yield under stress conditions are: lower reduction in water potential, reduction in $\mathrm{CO}_{2}$ assimilation rates, prolonged stomatal closure, higher chlorophyll concentration and deep roots (with less lateral branching). The lack of water reduces the turgor of the cells and, consequently, their growth, an increase in the synthesis of the abscisic acid (ABA), which induces stomatal closure and reduces $\mathrm{CO}_{2}$ assimilation (Bernini et al., 2016).

An important aspect in the selection of maize cultivars tolerant to water deficit is that the character which imparts tolerance must be genetically related to grain production and should be highly inheritable, easy to measure, low cost, nondestructive, stable and should not be associated with decreased yield under condition without water stress (Ribault et al., 2009). Thus, the most known secondary characters are the number of ears per plant, which should increase in tolerant genotypes, the interval between male and female flowering, which should decrease in tolerant cultivars, stay-green should be increased as well as the number of branches on the tassel (Bänziger et al., 2000).

Cultivars showing an interval between male and female flowering less than five days under stress condition are considered tolerant (Cairns et al., 2013). Stay-green is a characteristic that allows the plant to maintain the green leaf area and photosynthetic activity for longer under drought conditions during grain filling, delaying leaf senescence. Additionally, the capacity to control stomatal opening, through which the plant limits its water loss, is considered an important mechanism, which allows the plant to continue $\mathrm{CO}_{2}$ assimilation, performing photosynthesis (Oliveira et al., 2002).

Landrace cultivars, for having higher genetic variability, show higher phenotypic plasticity, which may allow current populations to maintain their suitability as the conditions change. Only a small portion of the genetic variability of maize has been explored, and landrace cultivars, which are often exposed to drought stress, are an important source of alleles to seek tolerance (Ortiz et al., 2008) and should be conserved.

\section{Scientific Advances in Maize Tolerance to Water Deficit}

The genetic variability for the desirable characteristics of maize can be obtained through new combinations and intercrossing of the genotypes (Bernini et al., 2016). The adaptation to the environment with stress occurs when genetic alterations are fixed in the entire population of plants through natural selection or in individuals which undergo a stressful situation and change their physiology or morphology (Bernini et al., 2016). In the genetic improvement of maize in the scenarios of increased water stress, production stability and wide adaptation should be sought, increasing the tolerance (Bernini et al., 2016).

In Mexico, in the 1970 s, the CIMMYT started an improvement program against drought using maize populations of the plains, the 'Tuxpeño Sequia'. After more than eight selection cycles, it obtained gains of up to $144 \mathrm{~kg} \mathrm{ha}^{-1}$ year-1 under water stress condition (Cairns et al., 2013). In the end of the 1990s, the CIMMYT started an improvement program for South Africa, selecting cultivars for soils with low nitrogen content and drought, whose cultivars had $40 \%$ higher yield than hybrids under water stress condition (Bänziger et al., 2000; Setimela et al., 2013).

In the African continent, mainly in the sub-Saharan region, some drought tolerant cultivars have been developed. In Ethiopia, two OPV have been proposed, 'ACV3' and 'ACV6', which are relatively tolerant to drought (Edmeades et al., 1996). The hybrid 'CML442/CML444' has been widely used as a seed parent in the development of drought-tolerant hybrids in Eastern and Southern Africa, where many gains have been achieved (Bänziger et al., 2006). One of the most important strategies was the development of cultivars called 'DT' (Drought-tolerant) (Lunduka et al., 2017). Since the 1990s, DTs have been treated as part of the solution to maintain maize production, especially in family properties. Besides being tolerant to drought, DTs are more productive, around $40 \%$ more than the commercial cultivars used (Setimela et al., 2013). In recent tests, the hybrid 'DT CZH0616' showed stable yield in 44 sites, producing around 36\% more under water stress condition compared to the most sown cultivar (Setimela et al., 2017).

In the United States, for the "Corn Belt" region, which has the highest maize production in the country, in the decade of the 1970s, the genetic improvement already focused on yield and tolerance to abiotic stresses, such as drought (Campos et al., 2004). As a result, the Hybrid Pioneer AQUAmax ${ }^{\oplus}$ (Guo et al., 2014) was obtained. This hybrid is the result of a set of hybrids which have better yield under drought conditions, with stable production. The 'Agrisure Artesian ${ }^{\circledast \prime}$ hybrid from Syngenta company, like the AQUAmax ${ }^{\circledR}$, was developed through the sum of conventional improvement, selection of 
genes of landrace cultivars, with the use of molecular markers (Edmeades, 2013).

In Brazil, in 1982 the cultivar 'IAC Maya Latente' was developed, in which the "latent" character was incorporated as a response to drought and cold. With this factor, there is a prolongation of the vegetative stage under water deficit, allowing flowering to occur when the water condition is re-established, with fast development to complete the cycle (Miranda et al., 1986). In 1992, Embrapa Milho e Sorgo started the formation of the cultivar 'Sin EEL Flint' by means of recombinations with germplasm of 'Cateto', a Mexican landrace cultivar that has a high level of drought tolerance (Gama et al., 2003). Studies on tolerance to water deficit continue to be carried out in Brazil. When studying two maize hybrids: 'DKB 390' (tolerant) and 'BRS 1030' (sensitive), at different stages of development and combined to generate cumulative stresses during the cycle, at Embrapa Milho e Sorgo, Souza et al. (2016) concluded that the higher tolerance of 'DKB 390' can be attributed to the memory of prior exposure to water stress at different development stages.

Genetic transformation for tolerance to water stress has also been tested. The gene ZAR1 (Zea mays ARGOS), an auxin regulator related to organ size, was inserted in maize to increase yield and tested for drought tolerance (Guo et al., 2014). The ZAR1 gene has been shown to influence some traits of plants that are related to drought tolerance, such as reducing the interval between flowering, number of aborted grains and sterility. The company Monsanto has developed the hybrid 'MON 87460', which is a transgenic maize cultivar with drought tolerance, which has the 'Droughtgard ${ }^{\circledast '}$ trait (Chang et al., 2014).

Genetic transformation has also been used to interfere in the production of ethylene, a phytohormone that is synthesized in all plant tissues and induces leaf senescence (Habben et al., 2014). After water stress, the transgenic reduced ethylene synthesis, decreased the interval between female and male flowering and increased the number of grains per ear, resulting in an increase of $800 \mathrm{~kg} \mathrm{ha}^{-1}$. However, the authors emphasize that it is very simplistic to directly relate the suppression of ethylene with direct increase in yield.

Research needs to continue to be conducted around the world to improve maize tolerance to water deficit. For this, some technologies are promising, such as the selection assisted by molecular markers, which can double the gains of the conventional selection for drought tolerance (Chang et al., 2014). Genetic mapping through molecular markers can be used to identify the number and genetic positions of the Quantitative Trait Locus (QTL), associated with a specific genotype for water stress (Campos et al., 2004). These technologies, associated with conventional selection, can guarantee the necessary advances to make maize cultivars productive under water deficit conditions. The next step would be, in addition to developing new technologies, to perform local studies, aiming to explore the genetic variability available. This is because a technology or a cultivar that adapts and produces well in one place may not have the same performance or be accepted in (an)other site(s).

To ensure the production of food for future generations, besides thinking of guaranteeing an increase of production, the socioeconomic and cultural characteristics of the producers also need to be considered. Maize cultivars developed for the 'maize belt' region may be more directed towards increased yield, using the available resources better, especially higher water use efficiency, whereas a cultivar developed for African conditions should be able to guarantee production with few nutrients, including water. In the RS, Brazil, in particular, it is necessary to seek cultivars with shorter cycles, for use in rotation with soybean, with higher tolerance to water deficit and lower cost of the seed.

\section{Conclusions}

1. Landrace maize cultivars are a source of biodiversity with adaptation to the environments subject to water deficit, which makes them fundamental to ensure maize production in the future.

2. Advances in scientific research cited in the review with the maize crop in genetic improvement and biotechnology have contributed to increasing the adaptation in scenarios of water shortage.

3. To ensure food security in maize production, efforts are needed in local studies, exploring the variability and conditions of each environment.

\section{Literature Cited}

Andrade, R. V. de; Santos, M. X. dos; Ferreira, A. da S.; Oliveira, A. C. de. Avaliação de acessos de milho crioulo coletados na região central do Brasil. Revista Brasileira de Milho e Sorgo, v.1, p.6774, 2002. https://doi.org/10.18512/1980-6477/rbms.v1n2p67-74 Argenta, G.; Sangoi, L.; Silva, P. R. F. da; Rampazzo, C.; Gracietti, L. C.; Strieder, M. L.; Forsthofer, E. L.; Suhre, E. Análise econômica de estratégias de manejo na cultura do milho em dois ambientes contrastantes. Scientia Agrária, v.4, p.27-34, 2003. https://doi. org/10.5380/rsa.v4i1.1062

Bänziger, M.; Edmeades, G. O.; Beck, D.; Bellon, M.; Breeding for drought and nitrogen stress tolerance in maize: From theory to practice. México: CIMMYT, 2000. 68p.

Bänziger, M.; Setimela, P. S.; Hodson, D.; Vivek, B. Breeding for improved abiotic stress tolerance in maize adapted to Southern Africa. Agricultural Water Management, v.80, p.212-214, 2006. https://doi.org/10.1016/j.agwat.2005.07.014

Bergamaschi, H.; Matzenauer, R. O milho e o clima. Porto Alegre: EMATER, 2014. 84p.

Berlato, M. A.; Farenzena, H.; Fontana, D. C. Associação entre El Niño Oscilação Sul e a produtividade de milho no Estado do Rio Grande do Sul. Pesquisa Agropecuária Brasileira, v.40, p.423-432, 2005. https://doi.org/10.1590/S0100-204X2005000500001

Bernini, C. S.; Guimarães, P. de S.; Garcia, L. A. C.; Paterniani, M. E. A. G. Z. Caracteres fisiológicos e agronômicos em progênies interpopulacionais de milho selecionadas sob condições de déficit hídrico. Revista Brasileira de Milho e Sorgo, v.15, p.39-52, 2016. https://doi.org/10.18512/1980-6477/rbms.v15n1p39-52

Bianchetto, R.; Fontanive, D. E.; Cezimbra, J. C. G.; Krynski, A. M.; Ramires, M. F.; Antoniolli, Z. I.; Souza, E. L. Desempenho agronômico de milho crioulo em diferentes níveis de adubação no sul do Brasil. Revista Eletrônica Científica da UERGS, v.3, p.528545, 2017. https://doi.org/10.21674/2448-0479.33.528-545 
Boef, W. S. de; Thijssen, M.; Sthapit, B. Participatory crop improvement in a context of community biodiversity management: Introduction. In: Boef, W. S. de; Subedi, A.; Peroni, N.; Thijssen, M.; O'Keeffe, E. Community Biodiversity Management. Abingdon: Routledge, 2013. Chap.5, p.219-232.

Cairns, J. E.; Crossa, J.; Zaidi, P. H.; Grudloyma, P.; Sanchez, C.; Araus, J. L.; Thaitad, S.; Makumbi, D.; Magorokosho, C.; Bänziger, M.; Menkir, A.; Hearne, S.; Atlin, G. N. Identification of drought, heat, and combined drought and heat tolerant donors in maize (Zea mays L.). Crop Science, v.53, p.1335-1346, 2013. https://doi. org/10.2135/cropsci2012.09.0545

Campos, H.; Cooper, M.; Habben, J. E.; Edmeades, G. O.; Schussler. J. R. Improving drought tolerance in maize: A view from industry. Field Crops Research, v.90, p.1-34, 2004. https://doi. org/10.1016/j.fcr.2004.07.003

Chang, J.; Clay, D. E.; Hansen, S. A.; Clay, S. A.; Schumacher. T. E. Water stress impacts on transgenic drought-tolerant corn in the Northern Great Plains. Agronomy Journal, v.106, p.125-130, 2014. https://doi.org/10.2134/agronj2013.0076

Clerc, V. le; Bazante, F.; Baril, C.; Guiard, J.; Zhang, D. Assessing temporal changes in genetic diversity of maize varieties using microsatellite markers. Theoretical and Applied Genetics, v.110, p.294-302, 2005. https://doi.org/10.1007/s00122-004-1834-2

Edmeades, G. O. Progress in achieving and delivering drought tolerance in maize: An update. Ithaca: Nova York, 2013. 44p.

Edmeades, G. O.; Bänziger, M.; Mickelson, H. R.; Pena-Valdivia, C. B. Developing drought and low N-tolerant maize. México: CIMMYT, 1996. 557p.

EMATER - Empresa de Assistência Técnica e Extensão Rural. Relatório de atividades 2012. Porto Alegre: EMATER, 2012. 131p.

Fancelli, A. L.; Dourado Neto, D. Produção de milho. 2.ed. Guaíba: Agropecuária, 2000. 360p.

FAOSTAT - Food and Agriculture Organization of the United Nations. Statistical databases. Available on: <http://faostat.fao. org >. Accessed on: May 2018.

Fritsche-Neto, R.; Môro, G. V. Milho: Brasil amplia cultivo para atender demanda crescente. Visão Agrícola, v.13, p.12-16, 2015.

Gama, E. E. G. e; Santos, M. X. dos; Ferrão, R. G.; Meireles, W. F.; Pacheco, C. A. P.; Parentoni, S. N.; Guimarães, P. E. O. Potencial genético de um sintético de milho de grãos duros para formação de híbridos. Ciência Rural, v.33, p.615-619, 2003. https://doi. org/10.1590/S0103-84782003000400004

Grassini, P.; Bussel, L. G. J. van; Wart, J. van; Wolf, J.; Claessens, L.; Yanga, H.; Boogaard, H.; Groot, H. de; Ittersum, M. K. van; Cassman, K. G. How good is good enough? Data requirements for reliable crop yield simulations and yield-gap analysis. Field Crops Research. v.177, p.49-63, 2015. https://doi.org/10.1016/j.fcr.2015.03.004

Guo, M.; Rupe, M. A.; Wei, J.; Winkler, C.; Gonçalves-Butruille, M.; Weers, B. P.; Cerwick, S. F.; Dieter, J. A.; Duncan, K. E.; Howard, R. J.; Hou, Z.; Löffler, C. M.; Cooper, C.; Simmons, C. R. Maize ARGOS1 (ZAR1) transgenic alleles increase hybrid maize yield. Journal of Experimental Botany, v.65, p.249-260, 2014. https:// doi.org/10.1093/jxb/ert370

Habben, J. E.; Bao, X.; Bate, N. J.; DeBruin, J. L.; Dolan, D.; Hasegawa, D.; Helentjaris, T. G.; Lafitte, R. H.; Lovan, N.; Mo, H.; Reimann, K.; Schussler, J. R.; Transgenic alteration of ethylene biosynthesis increases grain yield in maize under field drought-stress conditions. Plant Biotechnology Journal, v.12, p.685-693, 2014. https://doi.org/10.1111/pbi.12172
IBGE - Instituto Brasileiro de Geografia e Estatística. Available on: $<$ https://censo2010.ibge.gov.br/>. Accessed on: Feb. 2018.

IPCC - Intergovernmental Panel on Climate Change. Climate change: Synthesis report. In: Team, C. W.; Pachauri, R. K.; Meyer, L. A. (eds.). Contribution of Working Groups I, II and III to the Fifth Assessment Report of the Intergovernmental Panel on Climate Change. Geneva: IPCC, 2014. Chap.3, p.75-91.

Kaufmann, M. P.; Reiniger, L. R. S.; Wizniewsky, J. G. A conservação integrada da agrobiodiversidade crioula. Revista Brasileira de Agroecologia, v.13, p.36-43, 2018.

Krug, C. A. Cultura e adubação do milho. In: Conagin, A. O milho no Brasil. São Paulo: Instituto Brasileiro de Potassa,1966. Cap.2, p.21-79.

Lunduka, R. W.; Mateva, K. I.; Magorokosho, C.; Manjeru, P. Impact of adoption of drought-tolerant maize varieties on total maize production in South Eastern Zimbabwe. Climate and Development, v.9, p.35-46, 2017. https://doi.org/10.1080/17565 529.2017.1372269

Machado, A. T.; Machado, C. T. de T.; Nass, L. L. Manejo da diversidade genética e melhoramento participativo de milho em sistemas agroecológicos. Revista Brasileira de Agroecologia, v.6, p.127-136, 2011.

Machado, A. T.; Santilli, J.; Magalhães, R. A agrobiodiversidade com enfoque agroecológico: Implicações conceituais e jurídicas. Brasília: Embrapa Informação Tecnológica, 2008. 102p.

Meirelles, L. R.; Rupp, L. C. D. Biodiversidade: Passado, presente e futuro da humanidade. Brasília: MMA, 2006. 85p.

Miranda, L. T. de; Miranda, L. E. C. de; Sawazaki, E.; Schmidt, N. C. Genetics of horizontal resistance: Measurement of the effects of B, P-WR, Pip and Korn on corn earworm resistance and yield. Maize Genetics Cooperation News Letter, v.56, p.32-33, 1986.

Oliveira, D. E. C. de; Santos, M. N. S. dos; Rufatto, S. Forma e tamanho dos grãos de milho da cultivar P3646 submetidos a diferentes condições de ar de secagem. Nativa, v.2, p.162-165, 2014. https:// doi.org/10.14583/2318-7670.v02n03a06

Oliveira, M. A. J. de; Bovi, M. L. A.; Machado, E. C.; Gomes, M. M. de A.; Habermann, G.; Rodrigues, J. D. Fotossíntese, condutância estomática e transpiração em pupunheira sob deficiência hídrica. Scientia Agricola, v.59, p.59-63, 2002. https://doi.org/10.1590/ S0103-90162002000100008

Ortiz, R.; Sayre, K. D.; Govaerts, B.; Gupta, R.; Subbarao, G. V.; Ban, T.; Hodson, D.; Dixon, J. M.; Ortiz-Monasterio, J. I.; Reynolds, M. Climate change: Can wheat beat the heat? Agriculture, Ecosystems \& Environment, v.126, p.46-58, 2008. https://doi.org/10.1016/j.agee.2008.01.019

Perry, L.; Sandweiss, D. H.; Piperno, D. R.; Rademaker, K.; Malpass, M. A.; Umire, A.; Vera, P. de la. Early maize agriculture and interzonal interaction in Southern Peru. Nature, v.440, p.76-79, 2006. https://doi.org/10.1038/nature04294

Prasanna, B. M. Diversity in global maize germplasm: Characterization and utilization. Bioscience Journal, v.37, p.843-855, 2012. https:// doi.org/10.1007/s12038-012-9227-1

Ribault, J. M.; Bétran, J.; Monneveux, P.; Setter, T. Drought tolerance in maize. In: Bennetzen, J. L.; Hake, S. C. (eds.). Handbook of maize: Its biology. Netherlands: Springer, 2009. Cap.16, p.311-344. https://doi.org/10.1007/978-0-387-79418-1_16 
Sandri, C.; Tofanelli, M. B. D. Milho crioulo: Uma alternativa para rentabilidade no campo. Pesquisa Agropecuária Tropical, v.38, p.59-61, 2008.

Setimela, P. S.; Kassie, G. T.; Erenstein, O.; MacRobert, G. N.; Magorokosho, C. A.; Tarekegne, D.; Makumbi, G. T.; Ndoro, D. F. Performance of elite drought tolerant in maize varieties tested on-farm Eastern and Southern Africa. In: International Annual Meetings American Society of Agronomy, 2013, San Antonio. Proceedings... San Antonio: SSSA, 2013. p.21-24.

Setimela, P. S.; Magorokosho, C. A.; Lunduka, R.; Gasura, E.; Makumbi, D.; Tarekegne, A.; Cairns, J. E.; Ndhlela, T.; Erenstein, O.; Mwangi, W. On-Farm yield gains with stress-tolerant maize in Eastern and Southern Africa. Agronomy Journal, v.109, p.406-416, 2017. https://doi.org/10.2134/agronj2015.0540
Silva, F. M. da; Alves, L. S.; Botelho Filho, F. B.; Silva, I. S. Liquidez dos contratos futuros de milho negociados na BM\&FBOVESPA. Revista de Administração e Negócios da Amazônia, v.9, p.26-44, 2017. https://doi.org/10.18361/2176-8366/rara.v9n1p26-44

Souza, T. C. de; Magalhães, P. C.; Castro, E. M. de; Duarte, V. P.; Lavinsky, A. O. Corn root morphoanatomy at different development stages and yield under water stress. Pesquisa Agropecuária Brasileira, v.51, p.330-339, 2016. https://doi. org/10.1590/S0100-204X2016000400005

Taiz, L.; Zeiger, E. Fisiologia vegetal. 5.ed. Porto Alegre: Artmed, 2013. 954p.

Tedeschi, R. G.; Cavalcanti, I. F. A.; Grimm, A. M. Influences of two types of ENSO on South American precipitation. International Journal of Climatology, v.33, p.1382-1400, 2013. https://doi. org/10.1002/joc.3519 